УДК 595.324-153.063

О. В. Кушнірик, аспірант,

О. І. Худий, к.б.н., доцент,

Л. В. Худа, к.б.н., доцент

Чернівецький національний університет імені Юрія Федьковича,

кафедра біохімії та біотехнології

вул. Коцюбинського, 2, Чернівці, 58012, Україна,

e-mail: kushniryk-olga@email.ua

\title{
ГІДРОЛІТИЧНА АКТИВНІСТЬ ТА ПОЖИВНА ЦІННІСТЬ SIMOCEPHALUS VETULUS (MULLER) ПРИ КУЛЬТИВУВАННI 3 РІЗНИМИ КОРМОВИМИ СУБСТРАТАМИ
}

\begin{abstract}
Запропоновано метод насичення каротиноїдами живих кормів риб на прикладі культури Simocephalus vetulus шляхом застосування як кормового субстрату двох видів каротинсинтезуючих дріжджів - Rhodotorula rubra та R. glutinis. Використання обох видів дріжджів роду Rhodotorula за запропонованою схемою забезпечує зростання вмісту каротиноїдів та загальних протеїнів у досліджуваній культурі зоопланктону. Встановлено підвищення ліпазної та амілазної активності у S. vetulus при вигодовуванні каротинсинтезуючими дріжджами.
\end{abstract}

Ключові слова: гідролітична активність, нутрієнти, культивування, зоопланктон, дріжджі.

Широке використання живих кормів у аквакультурі зумовлене не тільки перевагами їх нутрієнтного складу [9], а й вмістом комплексу гідролітичних ферментів [11]. На початкових етапах розвитку личинок риб травна система характеризується низькою ензиматичною активністю. У зв'язку з цим, травлення у риб при переході на зовнішнє живлення значною мірою забезпечується гідролітичними ферментами спожитого живого корму, які забезпечують автоліз [5]. Окрім того, екзогенне надходження гідролаз у кишечник личинок може викликати додаткову активацію низки власних протеїназ шляхом обмеженого протеолізу зимогенів [16].

На сьогоднішній день більшість технологій культивування живих кормів спрямована на корекцію їх нутрієнтного складу через насичення різноманітними есенціальними сполуками, зокрема каротиноїдами. За результатами попередньо проведених досліджень [3, 4], була встановлена можливість використання каротинсинтезуючих дріжджів роду Rhodotorula при культивуванні зоопланктону. Однак питання впливу зазначених кормових субстратів на показники гідролітичної активності у кладоцер залишається не з'ясованим. 


\section{Матеріали та методи досліджень}

Дослідження проводили на культурі S. vetulus (Cladocera). Культивування зоопланктону здійснювали на середовищі $\mathrm{ADaM}$ [15] у ємностях об'ємом 0,5 л за 16-годинного фотоперіоду та температури $22 \pm 1{ }^{\circ} \mathrm{C}$ в умовах кліматичної кімнати.

Як кормовий субстрат для зоопланктону використовували водні суспензії трьох видів дріжджів (S. cerevisiae, $R$. glutinis та $R$. rubra), стандартизовані за

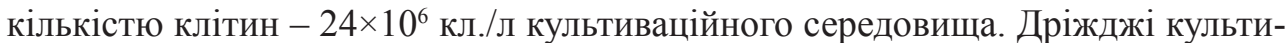
вували згідно технології, описаної раніше [4]. Для збагачення живого корму каротиноїдами тривалість пасажування зоопланктону становила 4 доби 3 інтервалом внесення дріжджів 48 год. Подача кормового субстрату досліджуваним ракоподібним відбувалася на початку експерименту та через 48 год. Проведення біохімічних аналізів здійснювали через 96 год. від початку експерименту.

Після попереднього заморожування у рідкому азоті проби гомогенізували із використанням фосфатного буфера $(\mathrm{pH} 7,4)$. Рівень сумарної ліпазної активності визначали за уніфікованим методом, принцип якого базується на спектрофотометричному вимірюванні зміни помутніння суспензії маслинової олії за дії ліпази [8]. Загальну протеолітичну активність досліджували при рН 7,4 за модифікованим методом Ансона із використанням казеїну як субстрату та обчислювали в мкмоль Туг/хв·мг білка [6]. Амілолітичну активність визначали амілокластичним методом Каравея [10] і виражали в мг крохмалю, перетвореного ферментом за 1 год. в перерахунку на 1 мг білка. Вміст загальних протеїнів оцінювали за методом Лоурі [17], загальних ліпідів - із застосуванням фосфорно-ванілінового реактиву [1]. Вміст загальних каротиноїдів визначали спектрофотометрично після їх осадження розчинами Карреза I і Карреза II, екстракції ацетоном та подальшої очистки із застосуванням петролейного ефіру [7]. Обрахунок проводили на 1 г сухої речовини.

Вірогідність відмінностей отриманих результатів оцінювали за допомогою однофакторного дисперсійного аналізу ANOVA при $\mathrm{p} \leq 0,05$.

\section{Результати досліджень та їх обговорення}

За результатами раніше проведених досліджень, використання каротинсинтезуючих дріжджів як кормових субстратів при 28-добовому культивуванні $S$. vetulus супроводжується подібною динамікою наростання культури зоопланктону, як і при застосуванні традиційно вживаних дріжджів S. cerevisiae. Окрім того, згодовування ракоподібним дріжджів роду Rhodotorula сприяє підвищенню в них вмісту основних нутрієнтів та накопиченню каротиноїдів [4].

Аналіз динаміки накопичення каротиноїдів засвідчив їх максимальний вміст у зоопланктоні на 4-ту добу культивування. У зв'язку з цим, довготривале культивування $S$. vetulus на каротинсинтезуючих дріжджах було доцільним замінити на 4-добове пасажування. Показано, що навіть при скороченому 
терміні використання дріжджів $R$. glutinis та $R$. rubra як кормових субстратів, вміст загальних протеїнів у культивованому зоопланктоні був вищим, ніж при застосуванні S. cerevisiae (табл. 1) [4].

Таблиця 1

Нутрієнтний склад $S$. vetulus при застосуванні різних кормових субстратів

\begin{tabular}{|l|c|c|c|}
\hline Кормовий субстрат & $\begin{array}{c}\text { Загальні } \\
\text { протеїни, мг/г }\end{array}$ & $\begin{array}{c}\text { Загальні ліпіди, } \\
\text { мг/г }\end{array}$ & $\begin{array}{c}\text { Загальні } \\
\text { каротиноїди, мг/г }\end{array}$ \\
\hline S. cerevisiae & $575,8 \pm 14,05$ & $174,8 \pm 4,56$ & $0,20 \pm 0,040$ \\
\hline R. rubra & $655,6 \pm 13,91$ & $132,9 \pm 22,70$ & $0,63 \pm 0,062$ \\
\hline R. glutinis & $645,8 \pm 35,48$ & $182,3 \pm 1,97$ & $0,71 \pm 0,074$ \\
\hline
\end{tabular}

Аналіз вмісту загальних каротиноїдів у $S$. vetulus при 4-добовому пасажуванні культури засвідчив зростання даного показника у 3,6 рази та у 3,2 рази за умов використання $R$. glutinis та $R$. rubra замість $S$. cerevisiae, відповідно (табл. 1). Відомо, що $R$. glutinis володіє значно вищою каротинсинтезуючою активністю, ніж $R$. rubra [2]. Запасання каротиноїдів у організмі ракоподібних відбувається в стінках кишечника $[14,19]$, у жирових клітинах та яйцях, інколи ïх присутність відмічається і у максилярних залозах та у гемолімфі, проте у епідермісі та кутикулі вони відсутні.

Споживання зоопланктону може позитивно вплинути на формування загального ензиматичного фону кишечника молоді риб [18]. Зважаючи на це, було прослідковано вплив каротинсинтезуючих дріжджів на гідролітичну активність у $S$. vetulus як перспективного кормового об'єкту для риб (табл. 2).

Таблиця 2

Гідролітична активність у $S$. vetulus при застосуванні різних кормових субстратів

\begin{tabular}{|l|c|c|c|}
\hline $\begin{array}{c}\text { Кормовий } \\
\text { субострат }\end{array}$ & $\begin{array}{c}\text { Загальна протеолітична } \\
\text { активність } \\
\text { (мкмоль / хв·мг білка) }\end{array}$ & $\begin{array}{c}\text { Ліпазна активність } \\
\text { (мкмоль / хв·мг білка) }\end{array}$ & $\begin{array}{c}\text { Амілолітична активність } \\
\text { (мг крохмалю / год. мг } \\
\text { білка) }\end{array}$ \\
\hline S. cerevisiae & $0,18 \pm 0,045$ & $0,02 \pm 0,007$ & $37,96 \pm 10,816$ \\
\hline R. rubra & $0,28 \pm 0,048$ & $2,19 \pm 0,697$ & $364,54 \pm 42,783$ \\
\hline R. glutinis & $0,04 \pm 0,008$ & $0,14 \pm 0,029$ & $245,77 \pm 46,709$ \\
\hline
\end{tabular}

Дослідження протеолітичної активності культури $S$. vetulus проводили при $\mathrm{pH} 7,4$, оскільки відомо, що найвища активність протеїназ у кишечнику кладоцер спостерігається при $\mathrm{pH}$ 6,8-7,4 [20]. Використання $R$. rubra замість $S$. cerevisiae призвело до незначного підвищення загальної протеолітичної активності у $S$. vetulus. Показано, що R. glutinis є продуцентом інгібітору карбоксипептидаз [13], що може бути однією із можливих причин пригнічення загальної 
протеолітичної активності у S. vetulus при пасажуванні на зазначеному виді дріжджів.

Загальновідомою є пряма залежність між ензиматичною активністю та кількістю перетворюваного субстрату. Тому підвищення ліполітичної активності у досліджуваних ракоподібних за умови використання $R$. glutinis та $R$. rubra може бути пов' язана із суттєвим накопиченням цими дріжджами ліпідів [12].

Заміна S. cerevisiae на дріжджі роду Rhodotorula в раціоні монокультури S. vetulus призвела до істотного зростання амілолітичної активності. Споживання живих кормів із таким підвищеним рівнем амілазної активності може сприяти ефективнішому переходу риб на штучні корми із значним вмістом інгредієнтів рослинного походження.

\section{Висновки}

1. Істотне накопичення каротиноїдів $S$. vetulus вже на 4 добу дозволяє скоротити термін пасажування культури на каротинсинтезуючих дріжджах з 28 до 4 діб. При цьому вміст основних нутрієнтів не змінюється.

2. Введення в раціон досліджуваного зоопланктону дріжджів роду Rhodotorula забезпечує підвищення ліпазної та амілазної активності культури.

\section{Список використаної літератури:}

1. Біохімія гідробіонтів / [Л. П. Вогнівенко, М. Ю. Євтушенко, М. В. Шевряков та ін.]. - Херсон: Олдіплюс, 2009. - 536 с

2. Кирица E. В. Направленный синтез каротиноидов у дрожжей и перспектива их использования: дис. на соискание науч. степени докт. биол. наук: 03.00.23 - биотехнология / Е. В. Кирица. - Кишинев: АНМ, 2005. - 129 c

3. Кушнірик O. В. Вміст каротиноїдів у Moina macrocopa (Straus, 1820) за умов вигодовування каротинсинтезуючими дріжджами Rhodotorula glutinis та Rhodotorula rubra / O. В. Кушнірик, О. I. Худий, Л. В. Худа // Ukr. Biochem. J. - 2014. - Vol. 86, № 5 (Suppl. 2). - Р. 199-200.

4. Кушнірик O. В. Застосування каротинсинтезуючих дріжджів Rhodotorula glutinis для культивування Simocephalus vetulus (Müller, 1776) у лабораторних умовах / [О. В. Кушнірик, М. М. Марченко, О. I. Худий та ін.] // Біологічні системи. - 2014. - Т. 6., Вип. 1. - С. 25-30.

5. Остроумова И. Н. Биологические основы кормления рыб. Изд-е 2-е, испр. и доп. / И. Н. Остроумова. СПб.: ГосНИОРХ, 2012. - 564 c.

6. Препараты ферментные. Метод определения протеолитической активности: ГОСТ 20264.2-88. - Москва: Издательство стандартов, 1988. - 15 с.

7. Продукты пищевые функциональные. Метод определения каротиноидов: ГОСТ Р 54058-2010. - Москва.: Стандартинформ, 2011. - 8 с

8. Скляров О. Я. Біохімія ензимів. Ензимодіагностика. Ензимопатологія. Ензимотерапія / О. Я. Скляров, Я. Сольський, М. М. Великий, Т. І. Бондарчук, Д. Дума. - Киев: Медицина, 2008. - 450 с.

9. Abowei J. F. N. A review of conventional and unconventional feeds in fish nutrition / J. F. N. Abowei, A. T. Ekubo // British Journal of Pharmacology and Toxicology. - 2011. - 2 (4). - P. 179-191.

10. Caraway W. T. A stable starch substrate for the determination of amylase in serum and other body fluids / W. T. Caraway // Am. J. Clin. Pathol. - 1959. - № 32. - P. 97-99.

11. Das P. Important live food organisms and their role in aquaculture / [P. Das, S. C. Mandal, S. K. Bhagabati et al.] // Frontiers in Aquaculture. - 2012. - № 5. - P. 69-86.

12. Enshaeieh $M$. Bioconversion of different carbon sources in to microbial oil and biodiesel using oleaginous yeasts / [M. Enshaeieh, A. Abdoli, I. Nahvi, M. Madani] // Journal of Biology and today's world. - 2012. Vol. 1 (2). - P. 82-92. 
13. Hernandez-Jondra M. Characterization of an intracellular inhibitor of the carboxypeptidase $\mathrm{R}$ from Rhodotorula glutinis / M. Hernandez-Jondra, C. Gancedo // Hoppe Seylers Z Physiol. Chem. - 1979. - 360 (7). - P. $913-917$.

14. Herring P. J. The carotenoid pigments of Daphnia magna Straus - I. The pigments of animals fed Chlorella pyrenoidosa and pure carotenoids / P. J. Herring // Comp. Biochem. Physiol. - 1968. - Vol. 24. - P. $187-203$.

15. Kluttgen B. ADaM, an artificial fresh water for the culture of zooplankton / B. Kluttgen, U. Dulmer, M. Engels et al. // Wat. Res. - 1994. - Vol. 28, No. 3. - P. 743-746.

16. Kolkovski S. Digestive enzymes in fish larvae and juveniles - implications and applications to formulated diets / S. Kolkovski // Aquaculture. - 2001. - 200. - P. 181-201.

17. Lowry O.H. Protein measurement with the Folin phenol reagent/ O. H. Lowry, N. J. Rosebrough, A.L. Farr, R.J. Randall // J. Biol. Chem.- 1951. -193. - P. 265-275.

18. Mitra G. Biochemical composition of zooplankton community grown in freshwater earthen ponds: Nutritional implication in nursery rearing of fish larvae and early juveniles / G. Mitra, P. K. Mukhopadhyay, S. Ayyappan // Aquaculture. - 2007. - Vol. 272 (1-4). - P. 346-360.

19. Pandolfini E. Grazing experiments with two freshwater zooplankters: fate of chlorophyll and carotenoid pigments / E. Pandolfini, I. Thys, B. Leporcq, J.-P. Descy // Journal of Plankton Research. - 2000. - Vol. 22, № 2. P. 305-319.

20. Von Elert E. Protease activity in gut of Daphnia magna: evidence for trypsin and chymotrypsin enzymes / [E. von Elert, M. K. Agrawal, C. Gebauer et al.] // Comparative Biochemistry and Physiology. Part B. - 2004. 137. - P. 287-296.

Стаття надійшла до редакції 29.01.2015

\section{О. В. Кушнирык, А. И. Худый, Л. В. Худа}

Черновицкий национальный университет имени Юрия Федьковича, кафедра биохимии и биотехнологии

ул. Коцюбинского, 2, Черновцы, 58012, Украина,

e-mail: kushniryk-olga@email.ua

\section{ГИДРОЛИТИЧЕСКАЯ АКТИВНОСТЬ И ПИТАТЕЛЬНАЯ ЦЕННОСТЬ SIMOCEPHALUS VETULUS (MULLER) ПРИ КУЛЬТИВИРОВАНИИ С РАЗЛИЧНЫМИ КОРМОВЫМИ СУБСТРАТАМИ}

\section{Резюме}

Предложен метод насыщения каротиноидами живых кормов рыб на примере культуры Simocephalus vetulus, путем применения в качестве кормового субстрата двух видов каротинсинтезирующих дрожжей - Rhodotorula rubra и R. glutinis. Использование дрожжей рода Rhodotorula по предложенной схеме обеспечивает увеличение содержания каротиноидов и общих протеинов в исследуемой культуре зоопланктона. Показано повышение липазной и амилазной активности у $S$. vetulus при кормлении каротинсинтезирующими дрожжами. Ключевые слова: гидролитическая активность, каротиноиды, нутриенты, культивирование, зоопланктон, дрожжи. 
O. V. Kushniryk, O. I. Khudyi, L. V. Khuda

Yuriy Fedkovych Chernivtsi National University,

Dapartment of Biochemistry and Biotechnology

2, Kotsjubynskyi str., Chernivtsi, 58012, Ukraine, e-mail: kushniryk-olga@email.ua

\section{HYDROLYTIC ACTIVITY AND NUTRITIONAL VALUE OF SIMOCEPHALUS VETULUS (MULLER) DURING CULTIVATION WITH DIFFERENT FEEDING SUBSTRATES}

\section{Summary}

The method of saturation the live feed for fish with carotenoids while applying as food substrates two species of carotenogenic yeast - Rhodotorula rubra and R. glutinis - was proposed on the example of $S$. vetulus culture. The usage of both yeast species Rhodotorula by proposed scheme provides an increase of carotenoids and total protein contents in the studied zooplankton culture. The increasing of lipase and amylase activities in $S$. vetulus was observed during their feeding on carotenoidproducing yeast.

Key words: hydrolytic activity, carotenoids, nutrients, cultivation, zooplankton, yeast. 